\title{
Separation and Determination of Small Quantities of Aluminum in Steel
}

\author{
Bruce B. Bendigo and Rosemond K. Bell
}

(December 21, 1959)

\begin{abstract}
A method is described for determining small amounts of aluminum (0.01 to 0.3 percent) in stainless and carbon steels. A perchloric-sulfuric acid solution of the steel is electrolyzed in a mercury cathode cell to remove most of the iron, and an extraction with chloroform is made to remove elements such as aluminum, residual iron, and titanium as cupferrates from a solution buffered at $p \mathrm{H} \mathrm{3.5.} \mathrm{These} \mathrm{elements} \mathrm{are} \mathrm{converted} \mathrm{from} \mathrm{cupferrates} \mathrm{to}$ perchlorates; all except aluminum are then extracted as cupferrates with chloroform from $4 \mathrm{~N}$ hydrochloric acid. Aluminum in the acid solution is determined photometrically with aluminon (ammonium aurintricarboxylate) at a wave length of approximately 540 millimicrons. An accuracy of \pm 0.005 percent aluminum is indicated.
\end{abstract}

\section{Introduction}

Steel may contain up to 1 percent or more of aluminum as an alloying agent, or it may contain less than 0.1 percent aluminum introduced either as a final deoxiding agent or from the processing materials.

The determination of aluminum in steel usually requires the separation of this element from major amounts of iron, as well as from certain other elements that would interfere in the final estimation of the aluminum by photometric methods such as the aluminon method [4]. ${ }^{1}$

A number of procedures have been used for this initial concentration step, for example, hydrolytic precipitation with sodium bicarbonate or sodium hydroxide, extraction of iron with ether [13], 8hydroxyquinoline precipitation in cyanide solution [1], electrolysis in a mercury cathode cell [3], extraction of iron cupferrate [2], and separation by ion exchange $[6,7]$.

Consideration of the relative advantages and limitations of the above-mentioned procedures, as well as preliminary experimental work, led to the selection of the electrolytic separation as best suited for the initial separation step in the procedure described in this paper.

In the method to be described, the sample of steel is dissolved in hydrochloric acid, perchloric acid is added, and the solution is evaporated to fumes of perchloric acid. The acid solution is electrolyzed in a mercury cathode cell to remove most of the iron. Aluminum, residual iron, and certain other elements not removed by electrolysis are extracted as cupferrates from the electrolyte at $p \mathrm{H} 3.5$ with chloroform. These elements are converted from cupferrates to perchlorates; all except aluminum are then extracted as cupferrates

Figures in brackets indicate the literature references at the end of this paper. with chloroform from $4 \mathrm{~N}$ hydrochloric acid. Aluminum in the aqueous portion is then determined photometrically with aluminon. Two days are usually required to complete a determination.

\section{Apparatus and Reagents}

Mercury Cathode Cell. A Dynacath type of mercury cathode cell was used to electrolyze the solutions.

Colorimeter. An Evelyn photometer, with voltage stabilizer and galvanometer, was used for the quantitative optical measurements. Matched test tubes (22 by $175 \mathrm{~mm}$ ) were used as absorption cells.

Cupferron Solution (60 g/liter). Dissolve $6 \mathrm{~g}$ of cupferron in $100 \mathrm{ml}$ of cold water and filter. Prepare fresh as needed.

Thioglycolic Acid Solution (100 ml/liter). Dilute $10 \mathrm{ml}$ of thioglycolic acid to $100 \mathrm{ml}$ with water and filter, if necessary. This solution is stable for 1 week.

Aluminon-Buffer Composite Solution. Dissolve 125 $\mathrm{g}$ of ammonium acetate in $250 \mathrm{ml}$ of water and add 20 $\mathrm{ml}$ of glacial acetic acid. Filter through a tight paper. While stirring this filtrate well, add first a solution of $0.250 \mathrm{~g}$ of aluminon (ammonium aurintricarboxylate) dissolved in $50 \mathrm{ml}$ of water, followed by a solution of $0.5 \mathrm{~g}$ of benzoic acid dissolved in 20 $\mathrm{ml}$ of methanol. Dilute the resulting solution to $500 \mathrm{ml}$, add $250 \mathrm{ml}$ of glycerol, and stir well. Store in a dark glass-stoppered bottle.

Standard Aluminum Solution $A(1 \mathrm{ml}=1.00 \mathrm{mg}$ aluminum). Transfer $1.000 \mathrm{~g}$ of high-purity aluminum to a 1-liter volumetric flask. Add $50 \mathrm{ml}$ of hydrochloric acid $(1+1)^{2}$ and heat gently until the metal is completely dissolved. Cool to room temperature, dilute to the mark, and mix.

2 Hydrochloric acid $(1+1)$ denotes 1 volume of concentrated hydrochloric acid, sp gr 1.18, diluted with 1 volume of water. Nitric acid $(1+1)$ denotes 1 volume of nitric acid, sp gr 1.42, diluted with 1 volume of water. Sulfuric acid $(1+1)$ denotes 1 volume of sulfuric acid, sp gr 1.84 , diluted with 1 volume of water. If no dilution is specified, the concentrated reagent is meant. 
Standard Aluminum Solution $B(1 \mathrm{ml}=0.05 \mathrm{mg}$ aluminum). Transfer exactly $50 \mathrm{ml}$ of the standard aluminum solution $\mathrm{A}$ to a 1-liter volumetric flask. Add $10 \mathrm{ml}$ of perchloric acid $(70$ to $72 \%$ ), dilute to the mark, and mix. This solution should be prepared as needed.

Dinitrophenol Indicator ( 0.2 g/liter $)$. Dissolve 20 $\mathrm{mg}$ of 2,4-dinitrophenol in $100 \mathrm{ml}$ of water.

\section{Procedure}

Transfer $5 \mathrm{~g}$ of the steel sample $(0.01$ to 0.3 percent aluminum) to a $600-\mathrm{ml}$ beaker and add $75 \mathrm{ml}$ of hydrochloric acid $(2+1)$. Heat gently until the sample is decomposed. Carefully add nitric acid $(1+1)$ to oxidize the iron and add $20 \mathrm{ml}$ in excess. Cool and add $50 \mathrm{ml}$ of perchloric acid $(70$ to $72 \%$ ). Evaporate the solution to fumes of perchloric acid, cover the beaker, and continue the heating for 10 min. If the chromium exceeds 5 percent, add hydrochloric acid in small portions to the hot perchloric acid solution until no more chromyl chloride is volatilized. Cool, add $200 \mathrm{ml}$ of water, and boil for several minutes. Remove from the heat, add paper pulp, and let stand until the precipitate settles. Filter through a close-textured paper containing paper pulp. Wash 10 times with sulfuric acid $(1+99)$ and reserve the filtrate.

Transfer the paper and contents to a $30-\mathrm{ml}$ platinum crucible. Char the paper and ignite under good oxidizing conditions at $500^{\circ} \mathrm{C}$ until the carbon is destroyed. Cool, add 2 drops of sulfuric acid $(1+1)$, and 5 to $10 \mathrm{ml}$ of hydrofluoric acid (48 percent) to the ignited residue. Heat the crucible in an air bath until the acids are expelled. Cool the crucible, and fuse the residue with $1 \mathrm{~g}$ of fused sodium bisulfate. Cool, add $20 \mathrm{ml}$ of sulfuric acid $(1+99)$ to the crucible, and heat gently until the melt is disintegrated. Transfer the contents to a $150-\mathrm{ml}$ beaker with sulfuric acid $(1+99)$. Boil for 5 min to insure complete solution of the aluminum salts and filter through a close-textured paper. Wash 5 times with sulfuric acid $(1+99)$ and discard the paper and contents. Cool the filtrate to room temperature and combine it with the reserved filtrate. Transfer the combined filtrates to a $500-\mathrm{ml}$ volumetric flash, dilute to the mark, and mix.

Transfer a $100-\mathrm{ml}$ aliquot portion of the solution (this portion is equivalent to $1 \mathrm{~g}$ of the sample) with a pipet to a mercury cathode cell containing $35 \mathrm{ml}$ of mercury. Add $5 \mathrm{ml}$ of sulfuric acid $(1+1)$ and electrolyze with a current of $15 \mathrm{amp}$ until the solution is colorless. About $15 \mathrm{~min}$ are required to remove $1 \mathrm{~g}$ of iron. Remove the electrolyte from the cell and wash the electrodes and cell with sulfuric acid $(1+99)$. Filter the electrolyte and washings through a medium-textured paper. Wash 5 times with sulfuric acid $(1+99)$ and discard the paper. Evaporate the filtrate to about $50 \mathrm{ml}$, then cool.

Neutralize the solution with ammonium hydroxide, using litmus as an indicator. Immediately acidify with hydrochloric acid $(1+1)$ and add $10 \mathrm{ml}$ in excess. Cool to room temperature and add ammonium hydroxide until the $p \mathrm{H}$ is between 3 and 7 , as indicated by a $p \mathrm{H}$ meter. Immediately add 10 $\mathrm{ml}$ of formic acid, and mix. Add ammonium hydroxide until the $p \mathrm{H}$ is $3.5 \pm 0.1$.

Transfer the buffered solution to a $250-\mathrm{ml}$ separatory funnel and cool in ice water for $15 \mathrm{~min}$. Disregard any insoluble salts. Add $25 \mathrm{ml}$ of cupferron solution, mix, and allow to stand for $15 \mathrm{~min}$ in ice water. Extract the cupferrates with $25-\mathrm{ml}$ portions of chloroform until the chloroform layer remains colorless. Allow the layers to separate while the funnel cools in ice water. Transfer the chloroform layers to a 300-ml Kjeldahl flask containing $10 \mathrm{ml}$ of water. Three or four extractions are usually sufficient. Discard the aqueous layer.

Heat the Kjeldahl flask in a water bath until the chloroform evaporates. Cool and add $10 \mathrm{ml}$ of nitric acid and $6 \mathrm{ml}$ of perchloric acid (70 to $72 \%$ ). Swirl the solution over a free flame until the perchloric acid condenses at the mouth of the flask. Cool, add $10 \mathrm{ml}$ of hydrochloric acid, and heat as directed before until perchloric acid condenses in the neck of the flask. Cool, add $50 \mathrm{ml}$ of water, and boil for $5 \mathrm{~min}$. Cool to room temperature.

Transfer the solution to a $250-\mathrm{ml}$ separatory funnel, wash the flask with $60 \mathrm{ml}$ of hydrochloric acid $(1+1)$, and add the washings to the funnel. Dilute the resulting solution to $100 \mathrm{ml}$, mix, and cool the funnel in ice water for $15 \mathrm{~min}$. Add $10 \mathrm{ml}$ of the cupferron solution, mix, and allow to stand in the ice water for $10 \mathrm{~min}$. Extract the cupferrates with one $25-\mathrm{ml}$ portion and several $10-\mathrm{ml}$ portions of chloroform until the chloroform layer remains colorless. Allow the layers to separate while the funnel cools in ice water. Discard the chloroform extracts. Transfer the aqueous portion to the same Kjeldahl flask used before.

Add $10 \mathrm{ml}$ of nitric acid $(1+1)$ and evaporate the solution to about $25 \mathrm{ml}$. Add $10 \mathrm{ml}$ of nitric acid and continue the evaporation until the perchloric acid condenses at the top of the flask. Cool, add $50 \mathrm{ml}$ of water, and boil for $5 \mathrm{~min}$. Cool to room temperature.

Transfer the solution to a $200-\mathrm{ml}$ volumetric flask, dilute to the mark, and mix. Transfer a 20-ml aliquot portion with a pipet to a $100-\mathrm{ml}$ volumetric flask. Add 3 drops of the dinitrophenol indicator solution to the flask and neutralize the solution by dropwise addition of ammonium hydroxide until the indicator turns yellow. Immediately add hydrochloric acid $(1+1)$ dropwise until the solution is colorless and then add 1 drop in excess. Add 2 $\mathrm{ml}$ of the thioglycolic acid solution and exactly $15.0 \mathrm{ml}$ of the aluminon-buffer composite solution. Because the composite solution is rather viscous, the pipet should drain for a minute or two. Place the flask in a 400-ml beaker containing boiling water and heat for exactly $4 \mathrm{~min}$ while maintaining the boiling temperature. Remove from the heat and let stand for $1 \mathrm{~min}$. Cool in running water for 4 min. Dilute to the mark and mix. Transfer a suitable portion of the solution to an absorption 
cell and measure the absorbancy or transmittancy at $540 \mathrm{~m} \mu$, using water as a reference solution. Obtain from a calibration curve the milligrams of aluminum in the final solution. Correct the value obtained for a reagent blank carried through all steps of the procedure.

\section{Preparation of the Calibration Curve}

To eight $100-\mathrm{ml}$ volumetric flasks transfer 0.0 , $0.5,1.0,2.0,3.0,4.0,5.0$, and $6.0 \mathrm{ml}$ of the standard aluminum solution B. Add 5 drops of perchloric acid $(70$ to $72 \%$ ) to each and dilute to $20 \mathrm{ml}$. Add 3 drops of dinitrophenol indicator to each flask, and follow with dropwise addition of ammonium hydroxide until the indicator turns yellow. Immediately add hydrochloric acid $(1+1)$ dropwise until the solution is colorless and add 1 drop in excess. Add $2 \mathrm{ml}$ of the thioglycolic acid solution and $15.0 \mathrm{ml}$ of the aluminon-buffer composite solution. Place each flask in a 400-ml beaker containing boiling water. Heat for exactly 4 min while maintaining the boiling temperature. Remove from the heat and let stand for $1 \mathrm{~min}$. Cool in running water for $4 \mathrm{~min}$, dilute to the mark, and mix. Measure the absorbancy or transmittancy of each solution as directed for the analysis sample. Plot the values obtained against milligrams of aluminum per $100 \mathrm{ml}$ of solution.

\section{Results}

The data in table 1 show the results obtained when the recommended procedure is used to determine aluminum in solutions of $1 \mathrm{~g}$ of stainless steel (having less than 0.001 percent aluminum) containing known additions of aluminum. The data in table 2 indicate the results obtained by applying the recommended procedure to various NBS standard samples.

TABLE 1. Results obtained for aluminum by applying the recommended procedure to solutions of one gram of a stainless steel $(\mathrm{Al}<0.001 \%)$ containing known additions of aluminum

\begin{tabular}{r|r|r}
\hline \hline \multirow{2}{*}{ Added } & \multirow{2}{*}{ Found a } & \multicolumn{2}{|c}{ Difference } \\
$m g$ & \multicolumn{1}{c}{$m g$} & \multicolumn{1}{c}{$m g$} \\
0.02 & 0.02 & 0.0 \\
.04 & .04 & .0 \\
.06 & .06 & .0 \\
.10 & .09 & -.01 \\
.10 & .09 & -.01 \\
.10 & .10 & .0 \\
.10 & .11 & +.01 \\
.20 & .21 & +.01 \\
.20 & .21 & +.01 \\
.30 & .29 & -.01 \\
.30 & .32 & \pm .02 \\
.50 & .47 & -.03 \\
.80 & .77 & -.03 \\
1.10 & 1.08 & -.02 \\
& & \\
\hline
\end{tabular}

a Corrected for blank on reagents plus the steel.
TABLE 2. Results obtained for aluminum by applying the recommended procedure to various National Bureau of Standards standard steels

\begin{tabular}{|c|c|c|c|}
\hline $\begin{array}{l}\text { NBS stand- } \\
\text { ard steel }\end{array}$ & Found & $\begin{array}{l}\text { Certificate } \\
\text { value }\end{array}$ & Type of steel \\
\hline & $\%$ & $\%$ & \\
\hline 1164 & $\begin{array}{r}0.0043 \\
.0048\end{array}$ & a 0.005 & Si $0.5, \mathrm{~V} 0.3$ \\
\hline 1166 & $\begin{array}{l}.014 \\
.015\end{array}$ & a. 015 & $\begin{array}{l}\text { Open-Hearth Iron (Ti } \\
0.06) \text {. }\end{array}$ \\
\hline 1162 & $\begin{array}{l}.022 \\
.021\end{array}$ & a. 023 & $\begin{array}{l}\text { Ni } 0.7, \text { Cr } 0.7, \text { Sn } 0.07 \text {, } \\
\text { Ti } 0.04, \text { Nb 0.1, Zr } 0.06 \text {. }\end{array}$ \\
\hline $111 \mathrm{~b}$ & $\begin{array}{l}.042 \\
.044\end{array}$ & .042 & Ni 1.8 , Mo 0.3 . \\
\hline $65 \mathrm{~d}$ & $\begin{array}{l}.056 \\
.056 \\
.055 \\
.057 \\
.058\end{array}$ & .059 & $\begin{array}{l}\text { Basic Electric Stcel } \\
(\mathrm{C} 0.3) \text {. }\end{array}$ \\
\hline $22 \mathrm{c}$ & $\begin{array}{l}.110 \\
.114\end{array}$ & .116 & Bessemer Steel. \\
\hline 1167 & $\begin{array}{l}.156 \\
.150\end{array}$ & a. 16 & $\begin{array}{l}\text { Ti } 0.3, \text { W } 0.2, \text { Zr } 0.1 \text {, } \\
\text { Nb } 0.3, \text { Ta } 0.2 \text {. }\end{array}$ \\
\hline 1165 & $\begin{array}{l}.185 \\
.187\end{array}$ & a. 19 & $\begin{array}{l}\text { Open-Hearth Iron ( } \mathrm{Ti} \\
0.2) \text {. }\end{array}$ \\
\hline
\end{tabular}

a Provisional value.

\section{Discussion}

After electrolysis in the mercury cathode cell, the electrolyte contains all of the aluminum, titanium, vanadium, zirconium, phosphorus, alkaline earths, and residual iron and chromium. It will also contain the earth acids and tungsten which have escaped filtration, as well as relatively large amounts of perchloric acid. Further separations of aluminum are based on the fact that aluminum cupferrate is extracted by chloroform from a solution buffered between $p \mathrm{H} 2$ and 5 [5], but not from a solution $4 N$ in acid $[11,14]$.

There are several advantages gained by an extraction of cupferrates from the electrolyte buffered at $p \mathrm{H}$ 3.5. At this $p \mathrm{H}$, aluminum is separated from phosphate. This is of possible utility when aluminum is determined as the oxide after precipitation

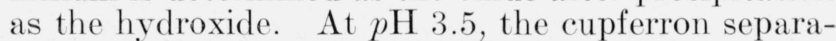
tion of aluminum removes the relatively large amounts of perchloric and sulfuric acids which would interfere by forming ammonium salts later in the photometric determination of the aluminum. Most of the residual chromium in the electrolyte is also removed in the aqueous phase. Aluminum cupferrate is completely extracted by chloroform from a solution that is buffered with formic acid to $p \mathrm{H}$ 3.5. Measured quantities of aluminum were added to and extracted from this buffered solution, and very little, if any, of the added aluminum was lost, as can be seen from the results shown in table 3 .

The chloroform extraction of cupferrates from a $4 N$ hydrochloric acid separates interfering elements from the aluminum, which remains in the aqueous portion. Very small amounts of chromium may accompany the aluminum. However, tests showed that $0.15 \mathrm{mg}$ of chromium did not interfere in the 
TABLE 3. Results obtained for aluminum when aluminum cupferrate is extracted with chloroform from a solution buffered at $p \mathrm{H} 3.5$ with formic acid

\begin{tabular}{c|c|c}
\hline \multirow{2}{*}{ Added } & Found & Difference \\
\cline { 2 - 3 } & & \\
\hline$m g$ & $m g$ & $m g$ \\
0.27 & 0.26 & -0.01 \\
.50 & .49 & -.01 \\
.73 & .73 & .00 \\
1.03 & 1.01 & -.02 \\
\hline
\end{tabular}

photometric determination of the aluminum with aluminon. After the small amount of unextracted cupferron has been destroyed, the aluminum can be determined by any suitable method. When aluminum is present in small quantities, it is determined conveniently by the aluminon-photometric method. When larger amounts of aluminum are present, it can be determined gravimetrically, if desired. Tests were made for aluminum remaining in the aqueous solution after extraction with chloroform from a $4 \mathrm{~N}$ acid solution to which cupferron and known quantities of aluminum had been added. These results are given in table 4 .

TABLE 4. Results obtained for aluminum in the aqueous solution after a $4 \mathrm{~N} \mathrm{HCl}-\mathrm{HClO}_{4}$ solution containing aluminum and excess cupferron is extracted with chloroform

\begin{tabular}{c|c|c}
\hline \hline Added & Found & Difference \\
\cline { 1 - 1 }$m g$ & $m g$ & $m g$ \\
0.02 & 0.03 & +0.01 \\
.04 & .04 & .00 \\
.06 & .06 & .00 \\
.08 & .08 & .00 \\
\hline
\end{tabular}

It is well established that iron can be separated from aluminum by electrolysis in a mercury cathode cell $[8,9]$. Wiberley and Bassett [16] suggests a one-normal mixture of perchloric-sulfuric acids as the electrolyte. It is not necessary to completely remove the iron because small remaining quantities are separated later in the recommended procedure. Because chromium is removed slowly by electrolysis, it is advantageous, with steels containing more than 5 percent chromium, to remove most of the chromium as chromyl chloride prior to electrolysis. No significant errors occur if less than $50 \mathrm{mg}$ of chromium remain before electrolysis. No aluminum is lost during electrolysis, according to Scherrer and Mogerman [12]. When known quantities of aluminum were added to solutions representative of those present after electrolysis, and the recommended procedure followed, quantitative results were obtained, as shown by the data in table 5 .

The recommended aluminon photometric procedure has been described by Pellowe and Hardy [10]. The optimum amount of aluminum in the final aliquot is between 0.02 and $0.30 \mathrm{mg}$. It should be
TABLE 5. Results obtained for aluminum in synthetic solutions representative of the electrolyte remaining after electrolysis with a mercury cathode cell

\begin{tabular}{|c|c|c|c|c|c|c|}
\hline \multicolumn{3}{|c|}{ Aluminum } & \multicolumn{4}{|c|}{ Composition of solutions } \\
\hline Added & Found & Difference & Iron & $\begin{array}{l}\text { Chro- } \\
\text { mium }\end{array}$ & Titanium & Vanadium \\
\hline $\begin{array}{c}m g \\
0.25 \\
.50 \\
.75\end{array}$ & $\begin{array}{c}m g \\
0.26 \\
.50 \\
.72\end{array}$ & $\begin{array}{l}m g \\
+0.01 \\
\quad .00 \\
-.03\end{array}$ & $\begin{array}{r}m g \\
1 \\
1 \\
1\end{array}$ & $\begin{array}{l}1 \\
1 \\
1\end{array}$ & $\begin{array}{r}m g \\
0.5 \\
.5 \\
.5\end{array}$ & $\begin{array}{rr} & \\
& 0.5 \\
& .5 \\
.5\end{array}$ \\
\hline
\end{tabular}

noted that the color of the solution has a significant temperature coefficient [15]. Therefore, when absorbancy measurements are made, the temperature of test solutions and standards should not differ by more than $5^{\circ} \mathrm{C}$.

As described, the method recommended in this paper is used to determine total aluminum. If desired, however, the acid-insoluble aluminum can be separated from that which is soluble by filtering the hydrochloric acid solution of the sample; each can then be determined separately in the solution and residue.

The recommended sample size of $5 \mathrm{~g}$ will minimize the error due to the segregation of aluminum in the alloy. In the procedure described, an aliquot equivalent to $1 \mathrm{~g}$ of steel is taken for electrolysis.

\section{References}

[1] ASTM Methods for chemical analysis of metals, p. 213 (American Society for Testing Materials, Philadelphia, Pa., 1956).

[2] ibrid, p. 251.

[3] ibid, p. 282.

[4] C. H. Craft and C. R. Makepeace, Ind. Eng. Chem. Anal. Ed. 1\%, 206 (1945).

[5] N. H. Furman, W. B. Mason, and J. S. Pekola, Anal. Chem. 21, 1325 (1949).

[6] J. V. Gilfrich, Anal. Chem. 29, 978 (1957).

[7] A. D. Horton and P. F. Thomason, Anal. Chem. 25, 1326 (1956).

[8] G. E. F. Lundell and J. I. Hoffman, Outlines of methods of chemical analysis, p. 94 (J. Wiley and Sons, Inc., New York, N.Y., 1938).

[9] J. A. Maxwell and R. P. Graham, Chem. Rev. 46, 482 (1950).

[10] E. F. Pellowe and F. R. F. Hardy, Analyst 79, 225 (1954).

[11] E. B. Sandell, Colorimetric determination of traces of metals, 3d ed., p. 221. (Interscience Pub., Inc., New York, N.Y., 1959).

[12] J. A. Scherrer and W. D. Mogerman, J. Research NBS 21, 105 (1938) RP1117.

[13] H. G. Short, Analyst 75, 420 (1950).

[14] N. Strafford and P. F. Wyatt, Analyst 72, 54 (1947).

[15] W. Werz and A. Neuberger, Arch. Eisenhuttenw. 26, 205 (1955).

[16] S. E. Wiberley and L. G. Bassett, Anal. Chem. 21, 609 (1949).

Washington, D.C.

(Paper 64A3-47) 